\title{
A management course for senior registrars
}

\author{
Peter Reder
}

\begin{abstract}
A course on management within a poychiatry training scheme contributes to senior registrars' preparation to become consultants. Sestions should impart factual knowledge and consider interpersonal components of the manogement process.
\end{abstract}

Newly appointed consultants tend to feel less well prepared for the myriad of management tasks that confront them than for the demands of the clinical work. While some learning has to wait for direct experience when in the job, preparation can occur through formal and informal tuition during the senior registrar years. Trainees can be provided with ongoing supervision about management (Reder, 1993), but a dedicated course allows specific topics to be addressed in greater detail. An opportunity arose to introduce such a course for the group of child psychiatry senior registrars in the North Thames (West) regional scheme, through five two-hour sessions over an academic term. The course is briefly described so that other psychiatry training schemes might consider whether to adopt it.

The aims of the course were to prepare senior registrars for the non-clinical components of a consultant's professional life and to become familiar with management processes. It was hoped to 'desensitise' the trainees to the complexities of management by mentioning many concepts and names (of job titles, committees, documents, and so on), with the opportunity to follow them up in homework tasks (Table 1) and recommended reading, which ranged from Bhugra \& Burns' Management for Psychiatrists (1995) to Lyn \& Jay's The Complete Yes Minister (1984) and articles selected from the Psychiatric Bulletin and the British Medical Journal. The trainees offered a list of issues they wished to be included, which coincided with many of the topics already planned. However, in addition, the course emphasised that awareness of management issues involves not only factual knowledge, but also reflection on interpersonal behaviour and group functioning.

The sessions were a mixture of didactic lectures, informal presentations, small group work and large group discussions. Presenters included senior trainers from within the scheme. recently appointed consultants and managers from a Trust associated with the scheme.

The topics to be included covered five main themes: the structure of the National Health Service (NHS); management by managers; meetings; consultant responsibilities; and becoming and being a consultant.

Session 1 on 'The Structure of the NHS' was presented by a consultant who also held a senior managerial position. The various tiers of the NHS were outlined (The Department of Health. Regions, health agencies, Trusts), how universities and the professional Colleges fitted in and the roles of regional advisers, regional representatives,

Table 1. Homework tasks

Ask your consultant regularly to pass over to you copies of management-related letters, memos, documents, minutes, and discuss in supervision.

Record the process of a team meeting and a committee, especlally the chairing and the members' participation. and discuss in supervision.

List the meetings your consultant attends and their terms of reference.

Arrange to shadow your manager for a day.

Map the organisational structure of your Trust.

Obtain and read: a business plan; a financial breakdown of the costs of the service; purchaser's service specifications; purchaser's required quallty standards; some of the Trust's policy documents (e.g. relating to complaints; access to health records; disciplinary procedures; equal opportunitles; recelving extracontractual referrals).

Obtain the salary structure and 'on-costs' of all staff in the team.

Ask your manager to identify the Trust's position on consultant responsibility in multidisciplinary teams.

keep asking questions, however apparently nalve (you will be surprised at who else does not know the answer, but has not asked for fear of appearing ignorant). 
postgraduate deans, the Central Approval Panel for Specialist Advisory Committees (CAPSAC), and the Joint Committee for Higher Psychiatric Training (JCHPT). The other major theme was the purchaserprovider split, how it operates through block contracts and extracontractual referrals (ECRs), and its impact on clinicians. Not surprisingly, the senior registrars were particularly concerned whether they would be able to influence purhasers' views and decisions. The forthcoming expansion of the GP fundholding structure was explored in open discussion, together with the implications for psychiatrists of joint commissioning between health agencies and local authorities.

The second session on Management by Managers' was presented by the director and the business manager of a local child and adolescent mental health service. They first mapped the structure of their Trust, including the composition of the board, the various managers' titles and roles and the committee structure. Most of the time was spent demonstrating how managers operate within the purchaser-provider split, such as the information regularly required, monitoring of quality standards, working to service specifications, strategic planning and marketing. The significant components of a budget were discussed and a typical business plan summarised. Trainees were invited to percetve Trust managers as sandwiched between the directives of government and purchasers on the one hand and the demands of service delivery by clinicians on the other. 'Macho' management styles, which give the illusion of control, are sometimes a defensive reaction to this dilemma.

Session 3 was on 'Meetings'. The trainees fed back information on the various types of meetings which their supervising consultants attend and these were analysed for their purpose and organisational relationships. The distinction between advisory and executtve committees was emphasised. A systemic approach was suggested, in which any committee is viewed as a sub-system of the larger organisation and therefore enacts professional and personal relationships of that larger system. A committee as a dynamic group was then discussed, with the overall messages that, even though participants are meant to help the chair progress the meeting as a work group', chairing is usually hard work. The trainees met in pairs to consider the questions: what information about a committee would you need to know before you can comprehend its functioning (i.e. its constitution, membership, history, internal dynamics, and so on)? what different reasons for attending committees could there be (such as to gather information or to be remembered by the organisation)? what interpersonal behaviour have you observed in committees and how can it be understood (e.g. 'blinding with science', implying that one person has spoken for everyone, allying with the chair, leaving mobile phones switched on)? Strategies for survival in committees were then able to be indentified.

'Consultant Responsibilities' were addressed in Session 4. The group first collated answers to the common question at consultant job interviews: why should this Trust employ a child psychiatrist?' Much of the time was devoted to considering consultants' responsibilities in multidisciplinary teams and prior to this session the trainees had been asked to write to relevant professional and NHS bodies, as well as their Trust managers, to seek their attitudes. Replies reflected the prevailing lack of clarity, which was of considerable surprise to the senior registrars (prompting some of them to write up the results of this fascinating exercise), but issues of power and influence, responsibility and accountability could be discussed. The British Medical Association's Consultant Handbook (1993) formed the basis for a presentation about terms of employment, including job plans and disciplinary structures.

The fifth session was called 'Becoming and Being a Consultant'. A recently advertised job description was analysed for the information given and important information that was unclear or missing. This allowed questions to be formulated which would need to be asked at informal interviews, such as the history of the post, the history of relationships around the service, covert expectations, possible opportunities and constraints. Finally, three recently appointed consultants (two of whom were 'graduates' of the scheme) fed back their experiences of making the transition from senior registrar to consultant and the lessons they had learned in the process.

Time constraints limited the range of topics that could be covered in the course and a session originally planned as 'Policies and Politics' had to be abbreviated. However, the reading list and homework tasks pointed the trainees towards important policy issues with which they should become familiar, such as access to health records, consent and confidentlality. It also would have been interesting to role play a committee. Nonetheless, the trainees reported that they found the course valuable, allowing them to feel more conversant with the managerial side of a consultant's life, while the presenters enjoyed the opportunity to present an aspect of their experience that they rarely have the opportunity to discuss.

\section{Acknowledgements}

I am very grateful to Drs Veira Bailey, Mike McClure, Begum Maitra, Tessa Leverton and Alison Westman, and Ms Karina Hedley and Mr Tom Convery for their contributions to the 
course, to Dr Matthew Hodes and Professor Elena Garralda for including it in the training programme and to the group of senior registrars for their enthusiastic participation.

\section{References}

BHUGRA, D. \& BURNS, A. (eds) (1995) Management for Psychiatrists (2nd edn). London: Gaskell.

BRTISH MEDICAL ASSOCIATION (1993) The Consultant Handbook (2nd edn). London: BMA.
LYN, J. \& JAY, A. (eds) (1984) The Complete Yes Minister: The Diarles of a Cabinet Minister by the Right Hon. James Hacker MP. London: Gulld.

REDER, P. (1993) Management supervision for senior reglstrars, an example from child psychiatry. Psychiatric Bulletin, 17, 420-421.

Peter Reder, Consultant and Lead Clinician, Child and Adolescent Services, Riverside Mental Health Trust, 1 Wolverton Gardens, London W6 7DQ

\title{
Gaskell Academic Series
}

\section{Interpersonal Factors in Origin and Course of Affective Disorders}

\author{
Edited by $\mathrm{Ch}$. Mundt, with the assistance of Hugh Freeman
}

This detailed overview of the latest research on affective disorders brings together authors of international background and repute. Both a theoretical and practical approach to the origin and course of affective disorders is presented, covering specific problems and settings. The principal areas covered are: personality factors, risk and course; social support; marital and family interaction; and intervention.

$\bullet £ 25.00 \bullet 396$ pp. $\bullet$ Hardback $1995 \bullet$ ISBN 1902241907

Available from bookshops and from the Publications

Department, Royal College of Psychiatrists, 17 Belgrave Square,

London SW1X 8PG (Tel. 0171-235 2351, extension 146) 